\title{
VERTEBRAL FRACTURES IN PATIENTS TREATED FOR FEMUR PROXIMAL THIRD FRACTURES
}

\author{
FRATURAS VERTEBRAIS EM PACIENTES TRATADOS DE FRATURAS DO TERÇO PROXIMAL DO FÊMUR
}

\author{
FRACTURAS VERTEBRALES EN PACIENTES TRATADOS POR FRACTURAS DEL TERCIO \\ PROXIMAL DEL FÉMUR
}

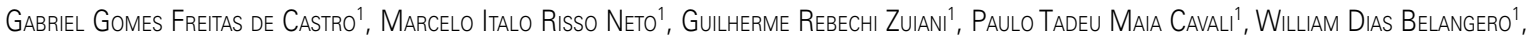
Ivan Guidolin Veiga', Wagner PasqualinI ${ }^{1}$, Marcos Antônio Tebet ${ }^{1}$, Élcio Landim ${ }^{1}$

\begin{abstract}
Objective: To investigate the prevalence of fractures of the vertebral bodies in patients with femur proximal third fracture. Methods: Crosssectional study conducted at Hospital de Clínicas, Unicamp, SP, Brazil, between May and December 2012, which referred the patients with proximal femur fracture to radiographs of the spine. Fractures were evaluated according to number, severity and localization, applying the Genant index. Results: Of the 15 subjects who completed the study, 14 had fractures of the vertebral bodies. The most commonly affected level was T8. There was no increased prevalence of fractures at the apex of the thoracic kyphosis and lumbar lordosis. Conclusion: There is strong epidemiological association between femur proximal third fractures and fractures of vertebral bodies caused by insufficiency
\end{abstract}

Keywords: Spine; Spinal fractures/epidemiology; Femoral fractures.

\section{RESUMO}

Objetivo: Pesquisar a prevalência de fraturas dos corpos vertebrais em pacientes com fratura do terço proximal do fêmur. Métodos: Estudo transversal realizado no Hospital de Clínicas da Unicamp, SP, Brasil, entre maio e dezembro de 2012, que submeteu os pacientes com fratura do terço proximal do fêmur a radiografias da coluna vertebral. As fraturas foram avaliadas segundo o número, a gravidade e a localização, aplicando-se o índice de Genant. Resultados: Dos 15 sujeitos que concluíram o estudo, 14 tinham fraturas dos corpos vertebrais. O nível mais comumente acometido foi o T8. Não se observou maior prevalência de fratura no ápice da cifose torácica e da lordose lombar. Conclusão: Existe forte associação epidemiológica entre fraturas do terço proximal do fêmur e fraturas de corpos vertebrais causadas por insuficiência.

Descritores: Coluna vertebral; Fraturas da coluna vertebral/epidemiologia; Fraturas do fêmur.

\section{RESUMEN}

Objetivo: Investigar la prevalencia de las fracturas de los cuerpos vertebrales en pacientes con fractura del tercio proximal del fémur. Métodos: Estudio transversal realizado en el Hospital de Clínicas, Unicamp, SP, Brazil, entre mayo y diciembre de 2012, en el cual, los pacientes con fractura del tercio proximal del fémur fueron sometidos a radiografías de la columna vertebral. Las fracturas se evaluaron de acuerdo con el número, la gravedad y la localización, aplicando el índice de Genant. Resultados: De los 15 sujetos que completaron el estudio, 14 tenían fracturas de los cuerpos vertebrales. El nivel más afectado fue T8. No hubo aumento de la prevalencia de fracturas en el vértice de la cifosis torácica y lordosis lumbar. Conclusión: Existe una fuerte asociación epidemiológica entre las fracturas del tercio proximal del fémur y las fracturas de los cuerpos vertebrales causadas por insuficiencia.

Descriptores: Columna vertebral; Fracturas de la columna vertebral/epidemiología; Fracturas del fémur.

\section{INTRODUCTION}

Fractures of the vertebral bodies are one of the main characteristics of osteoporosis. Their consequences, such as morbidity and use of the health care system resources, are well known. The prevalence of vertebral fractures increases with age and they are present in up to $26 \%$ of individuals aged over 50 , and up to $50 \%$ of women aged over 75 years. ${ }^{1}$

The presence of a vertebral fracture is a risk factor for other vertebral fractures and fractures in other skeletal regions and a more significant predictive factor than either bone mineral density or biochemical markers of bone metabolism. ${ }^{1,2}$

The number of fractured vertebrae increases the risk of new fractures in the spine and appendicular skeleton. Therefore, it is more appropriate to evaluate the vertebrae individually than to simply classify the spine as a whole using a binary system (fracture present or absent). ${ }^{1}$ Spinal deformity resulting from fractures is a contributing factor to back pain and low back pain, height loss, and the inability to perform daily tasks. ${ }^{3-5}$

Most fractures of the thoracic and lumbar spines are peculiar because, unlike fractures in the appendicular skeleton and cervical spine, their occurrence is not immediately discovered. An image exam is therefore required for diagnosis. ${ }^{6}$

The World Health Organization defines osteoporosis as bone mineral density, measured using bone densitometry, as a T-score of 2.5 standard deviations or more below normal. ${ }^{7}$ Faisal-Cury and Zacchello ${ }^{8}$ reviewed bone densitometry reports and observed a prevalence of osteoporosis in $32.7 \%$ of Brazilian women older

1. Department of Orthopedics andTraumatology, Faculdade de Ciências Médicas da Unicamp, Campinas, SP, Brazil.

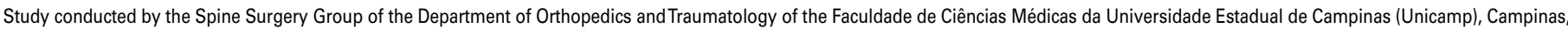
SP, Brazil.

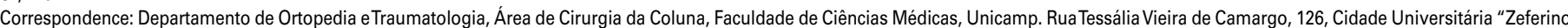
Vaz" - Campinas, SP, Brasil. 13083-887. mrisso@mpc.com.br,gbrcastro@gmail.com 
than 49 years of age. Costa-Paiva et $a /{ }^{9}$ found osteoporosis of the lumbar spine in $14.7 \%$ of menopausal women.

A simple chest $x$-ray may be sufficient to detect fractures of the thoracic vertebrae, though they may be subdiagnosed. ${ }^{10}$ Many clinicians consider the presence of an insufficiency fracture (a fracture from a minor trauma, such as a fall from the standing position) to be sufficient for a diagnosis of osteoporosis, regardless of bone mineral density. Although bone mineral density is important in evaluating the severity of the osteoporosis and in monitoring treatment, it is not essential for a diagnosis when the patient has prevalent fractures. ${ }^{7}$

The spinal deformity index (SDI) described by Genant et a ${ }^{11}$ is a tool that evaluates both the number of fractured vertebrae and their severity. This method permits the assessment of prevalent fractures in the first evaluation and incidental fractures in subsequent serial exams. ${ }^{11}$

Genant et $\mathrm{a} /{ }^{11}$ described a semiquantitative method to evaluate the thoracic and lumbar spines in search of spinal deformity caused by compression fractures present in patients with osteoporosis. Since then, various analytical studies have been conducted to compare the methods for diagnosing vertebral fractures associated with osteoporosis, pointing out the superiority of the Genant method in terms of reproducibility. 4,10,12-17

The official statement of the International Society for Clinical Densitometry indicates Genant's semiquantitative method as the most appropriate method for the detection of vertebral fractures. ${ }^{14}$

Crans et $\mathrm{al}^{7}$ described the prognostic importance of the Genant method as an accurate tool for determining the risk of prevalent and incidental vertebral fractures. In addition, it was observed that osteoporotic fractures are more common in the mid-thoracic region and thoracolumbar junction.

Fractures in the proximal region of the femur are the fractures most commonly treated with surgery. The evaluation of patients affected by fractures of the proximal third of the femur, when admitted to the hospital for treatment, covers an investigation of other fractures associated with falls, including fractures of the distal radius and vertebral fractures. ${ }^{18}$ Considering that the population at risk for falls at home is elderly, and that insufficiency fractures are a consequence of osteoporosis, the objective of this study is to evaluate the SDI in patients treated for fractures of the trochanter of the femur.

\section{MATERIALS AND METHODS}

The individuals admitted to the Hospital de Clínicas da Unicamp, Campinas, SP, Brazil, between May and December of 2012, for treatment of fractures in the hip region (the intertrochanteric region of the femur, the neck of the femur, and the subtrochanteric region of the femur) resulting from low-energy trauma, such as a fall in the home, underwent definitive treatment for the fracture and the thoracic and lumbar spines were $x$-rayed for semiquantitative analysis of fractures of the vertebral bodies.

Radiographic exams of the spine were conducted either during the postoperative period, while the patient was still hospitalized, or during return outpatient visits. The radiographs were taken in posteroanterior and lateral views to determine the presence of deformities in both the coronal and sagittal planes. The thoracic and lumbar spines were evaluated separately. The posteroanterior radiograph was analyzed for the presence of scoliosis and changes leading to a suspicion of neoplasia, such as erosion of the pedicle or bone lesions. The lateral radiograph was analyzed for the presence of spinal deformity resulting from vertebral compression fractures.

Patient exclusion criteria included patients with pathological fractures caused by tumors, patients younger than 50 years of age, victims of polytrauma, patients who had already undergone surgical treatment for some spinal disease in the thoracic or lumbar region, patients with congenital deformities of the thoracic or lumbar spine, and patients with scoliosis.
In the lateral radiograph, vertebrae T4 to $\mathrm{L} 4$ received a score of between 0 and 3 . The method is not viable in the presence of scoliosis, congenital spinal deformities, prior spinal bone surgeries, or the presence of spinal tumors, including metastases. As illustrated in Figure 1, a vertebra classified as having a grade 1 fracture presents a reduction of up to $25 \%$ in the height of one of the walls, grade 2 between 25 and $40 \%$ reduction in height, and grade 3 more than $40 \%$. The sum of the results classifies the spine with an index that represents the SDI, an example of which is shown in Figure 2.

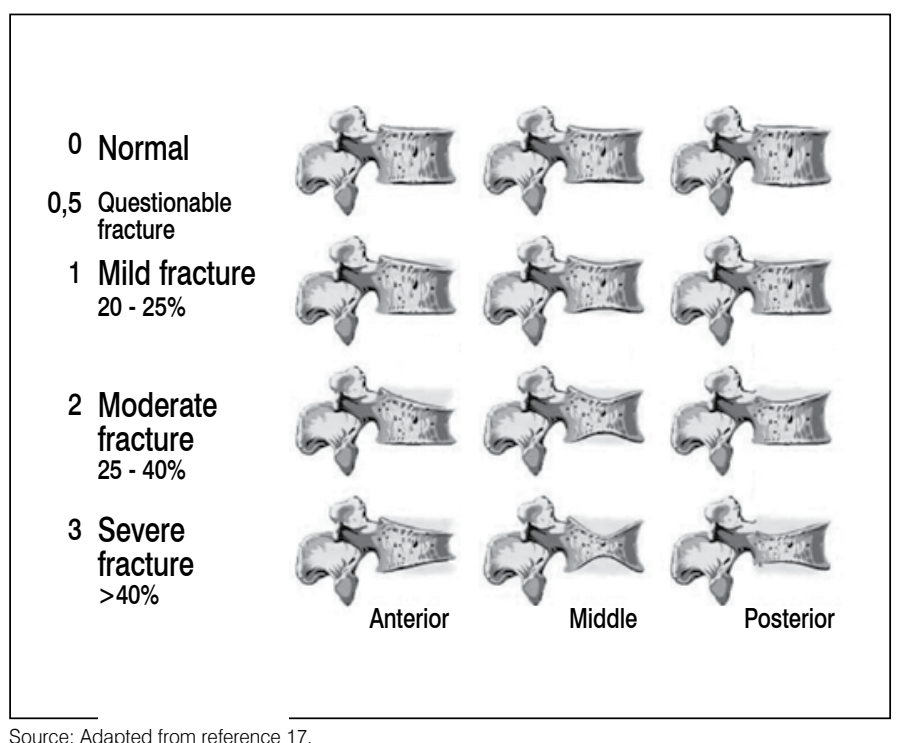

Figure 1. Grading of vertebral fractures according to the Genant semiquantitative method.

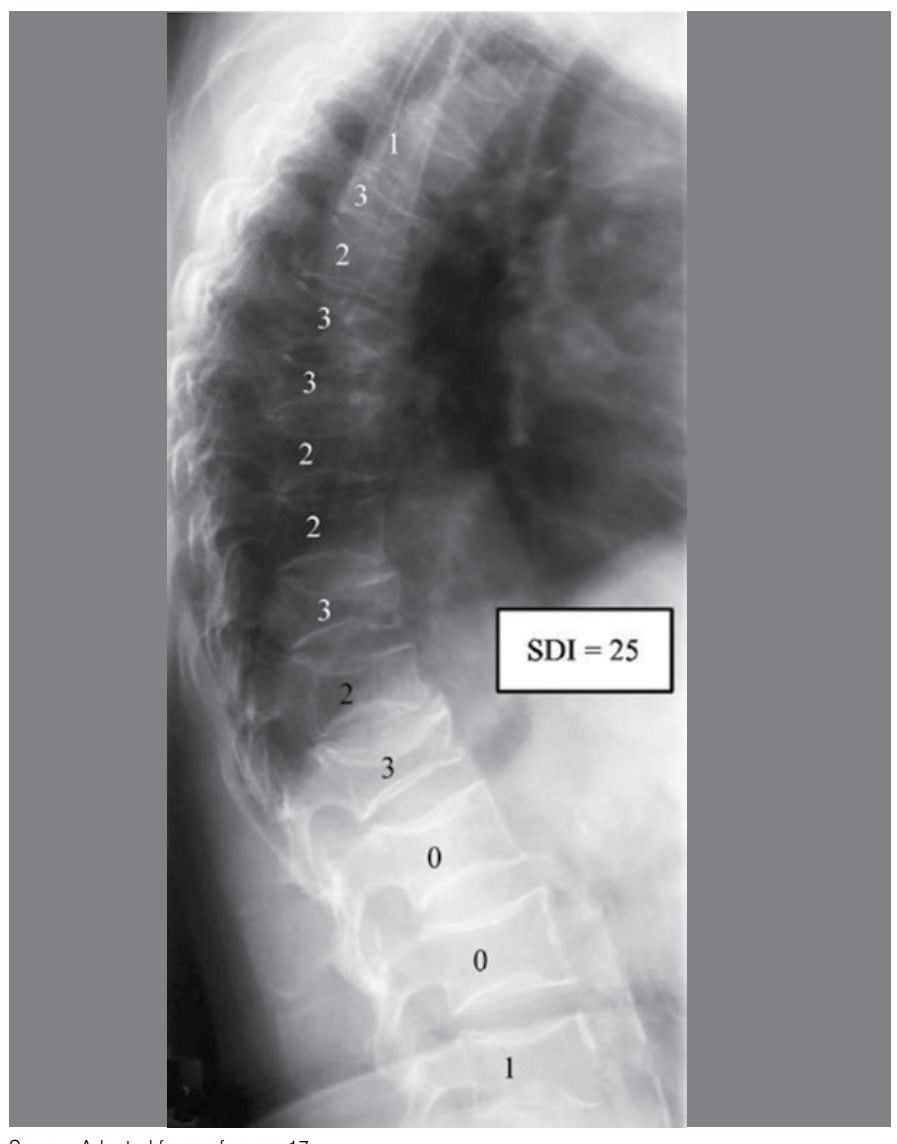

Source: Adapted from reference 17

Figure 2. Example of the calculation of the SDI from a spinal radiograph. 


\section{RESULTS}

There were 28 patients who initially agreed to participate in this study. However, ten patients decided not to participate because of difficulties in arranging transport for the return outpatient visits, two patients never showed up at any consultation following discharge, and one patient died during the postoperative period, the victim of a heart attack. In total, only 15 patients had spinal analysis. All patients read, agreed with, and signed the Informed Consent Form for the research, which was approved by the Research Ethics Committee of Faculdade de Ciências Médicas da Universidade Estadual de Campinas, SP, Brazil, registered as CAAE 04559312.0000.5404.

The average age was 74 years, ranging from 59 to 82 years of age. The group consisted of ten women and five men. The only trauma mechanism identified in the medical histories of the patients was a fall from a standing position, resulting in a fracture of the proximal femur. None of the patients experienced neurological deficit as a result of the vertebral fractures. The scores attributed to the vertebrae of the 15 patients studied are shown in Table 1.

Of all the patients studied, only one did not have vertebral fractures. We studied 195 vertebrae and fractures were found in $77(39.4 \%)$ of them. Most of these were classified as grade 1 ( $n=57$ or $74 \%$ ), and the most commonly fractured level was T8 $(n=9)$, followed by T7 $(n=8)$ and T9 $(n=8)$. (Table 2$)$ The apices of the kyphoses and lordoses of the patients were identified, and there were fractures of the apex of the kyphosis in six of them, while only one patient had a fracture in the apex of the lordosis. (Table 3)

The SDI calculations of four patients were lower than five, placing them in the low to medium probability of new fractures group. Six patients received an SDI between five and eight, indicating a high rate of new fractures. Five patients had an SDI higher than eight, these having already reached a stable plateau in terms of the risk of new fractures.

Table 1. Qualification of the fractures in relation to the vertebral levels in 15 patients. The asterisks indicate the vertebrae that represent the apex of the curves of the sagittal plane. Patient 9 had $L 1$ as the apex of kyphosis and L5 as the apex of lordosis.

\begin{tabular}{c|c|c|c|c|c|c|c|c|c|c|c|c|c|c}
\hline Patient & T4 & T5 & T6 & T7 & T8 & T9 & T10 & T11 & T12 & L1 & L2 & L3 & L4 & SDI \\
\hline 1 & 0 & 0 & $0^{*}$ & 0 & 0 & 0 & 0 & 0 & 0 & 0 & 0 & $0^{*}$ & 0 & 0 \\
\hline 2 & $1^{*}$ & 1 & 1 & 1 & 1 & 1 & 1 & 0 & 0 & 0 & $0^{*}$ & 0 & 2 & 9 \\
\hline 3 & 0 & 0 & 0 & 0 & 0 & 0 & $0^{*}$ & 0 & 0 & 2 & 0 & $3^{*}$ & 0 & 5 \\
\hline 4 & 3 & 3 & 1 & 2 & 1 & $1^{*}$ & 1 & 0 & 0 & 0 & 0 & 0 & $0^{*}$ & 12 \\
\hline 5 & 0 & 0 & 0 & 0 & 1 & 1 & $0^{*}$ & 1 & 1 & 1 & 3 & 1 & 0 & 16 \\
\hline 6 & 1 & 1 & 0 & 0 & $0^{*}$ & 0 & 0 & 1 & 0 & 0 & 0 & 0 & $0^{*}$ & 3 \\
\hline 7 & $0 *$ & 0 & 0 & 1 & 0 & 1 & 0 & 0 & 0 & 0 & 0 & 0 & $1^{*}$ & 3 \\
\hline 8 & 3 & 0 & 0 & 1 & $2^{*}$ & 0 & 0 & 0 & 0 & 0 & 0 & $0 *$ & 0 & 6 \\
\hline 9 & 0 & 2 & 1 & 1 & 1 & 1 & 1 & 1 & 3 & $3 *$ & 1 & 1 & 2 & 18 \\
\hline 10 & 0 & 0 & 0 & 0 & $1^{*}$ & 1 & 0 & 1 & 2 & 2 & 3 & 0 & $0^{*}$ & 10 \\
\hline 11 & 0 & 0 & $0^{*}$ & 1 & 1 & 0 & 0 & 0 & 1 & 1 & 1 & 0 & $0^{*}$ & 5 \\
\hline 12 & 0 & $0 *$ & 1 & 0 & 1 & 0 & 0 & 1 & 0 & 0 & 0 & $0 *$ & 0 & 3 \\
\hline 13 & 0 & 1 & 1 & 2 & 1 & $0 *$ & 1 & 0 & 0 & 1 & 0 & 0 & $0^{*}$ & 7 \\
\hline 14 & 1 & 0 & 1 & 0 & $0^{*}$ & 1 & 2 & 1 & 0 & 1 & 0 & 1 & $0^{*}$ & 8 \\
\hline 15 & 0 & 1 & 2 & $2 *$ & 0 & 1 & 1 & 0 & 0 & 0 & 0 & 0 & $0^{*}$ & 7 \\
\hline 12
\end{tabular}

Table 2. Distribution of the number and grade of fractures by vertebral level.

\begin{tabular}{c|c|c|c|c}
\hline Level/Fracture & $\mathbf{N}$ & Grade 1 & Grade 2 & Grade 3 \\
\hline $\mathrm{T} 4$ & 5 & 3 & 0 & 2 \\
\hline $\mathrm{T} 5$ & 6 & 4 & 1 & 1 \\
\hline $\mathrm{T} 6$ & 7 & 6 & 1 & 0 \\
\hline $\mathrm{T} 7$ & 8 & 5 & 3 & 0 \\
\hline $\mathrm{T} 8$ & 9 & 8 & 1 & 0 \\
\hline $\mathrm{T} 9$ & 8 & 8 & 0 & 0 \\
\hline $\mathrm{T} 10$ & 6 & 5 & 1 & 0 \\
\hline $\mathrm{T} 11$ & 6 & 6 & 0 & 0 \\
\hline $\mathrm{T} 12$ & 4 & 2 & 1 & 1 \\
\hline $\mathrm{L} 1$ & 7 & 4 & 2 & 1 \\
\hline $\mathrm{L} 2$ & 4 & 2 & 0 & 2 \\
\hline $\mathrm{L} 3$ & 4 & 3 & 0 & 1 \\
\hline $\mathrm{L} 4$ & 3 & 1 & 2 & 0 \\
\hline
\end{tabular}

Table 3. Level of the apices of the curves of the sagittal plane by patient. In parentheses, the grade attributed of the fracture of that vertebra. Vertebra L5 is not considered in the calculation of the spinal deformity index.

\begin{tabular}{c|c|c}
\hline Patient & Apex of kyphosis & Apex of lordosis \\
\hline 1 & $\mathrm{~T} 6(0)$ & $\mathrm{L} 3(0)$ \\
\hline 2 & $\mathrm{~T} 4(1)$ & $\mathrm{L} 2(0)$ \\
\hline 3 & $\mathrm{~T} 10(0)$ & $\mathrm{L} 5$ \\
\hline 4 & $\mathrm{~T} 9(1)$ & $\mathrm{L} 4(0)$ \\
\hline 5 & $\mathrm{~T} 10(0)$ & $\mathrm{L} 5$ \\
\hline 6 & $\mathrm{~T} 8(0)$ & $\mathrm{L}(0)$ \\
\hline 7 & $\mathrm{~T} 4(0)$ & $\mathrm{L}(1)$ \\
\hline 8 & $\mathrm{~T} 8(2)$ & $\mathrm{L}(0)$ \\
\hline 9 & $\mathrm{~L} 1(3)$ & $\mathrm{L} 4(0)$ \\
\hline 10 & $\mathrm{~T} 8(1)$ & $\mathrm{L} 4(0)$ \\
\hline 11 & $\mathrm{~T} 6(0)$ & $\mathrm{L} 3(0)$ \\
\hline 12 & $\mathrm{~T} 5(0)$ & $\mathrm{L} 4(0)$ \\
\hline 13 & $\mathrm{~T} 9(0)$ & $\mathrm{L} 4(0)$ \\
\hline 14 & $\mathrm{~T} 8(0)$ & $\mathrm{L} 4(0)$ \\
\hline 15 & $\mathrm{~T} 7(2)$ &
\end{tabular}

\section{DISCUSSION}

This study evaluated a population at high risk for vertebral fractures from falls and low-energy traumas. The number of subjects who participated in the study was much lower than expected. This was attributed to problems related to transport between the patients' homes and the hospital for postoperative follow-up, and to the lack of cooperation from family members to accompany outpatient visits, given that the study recruited elderly individuals with limited mobility.

It was observed that the Genant evaluation method is a useful tool for detecting fractures of the vertebral bodies. ${ }^{4,10-17}$ An assessment of the spine of an elderly patient can be performed in several different health care scenarios, from the basic health care unit to a tertiary hospital. ${ }^{11}$ The discovery of fractures of the vertebral bodies alerts the doctor and the patient to the bone quality of the individual, because fractures are a sign that something needs to be done to prevent a more serious condition, such as related fractures of the proximal region of the femur in this study. ${ }^{18}$

In a study to analyze the prognostic importance of the SDI, the progression of the number and grade of fractures in a population of postmenopausal women was noted. Two grade 1 fractures had the same value as one grade 2 fracture, and two grade 2 fractures had the same value as the sum of one grade 1 fracture and one grade 3 fracture. Thus, it was possible to assess the result of treatment through a serial analysis of spinal radiographs. When the SDI exce- 
eds a score of five, the risk of new fractures increases considerably. When it exceeds a score of eight, the risk of new fractures reaches a plateau. This occurs because the evaluation is performed for 13 vertebrae (from T4 to L4), so it is natural that at some point, there are no more vertebrae to be fractured. As the score increases, the risk of new fractures would eventually reach zero. ${ }^{7}$

Regarding the evaluation of vertebral fractures, the presence of fractures in 14 of the 15 subjects evaluated was documented. This number can be interpreted as a warning of the need to investigate the spine in all elderly patients with fractures in any other part of the skeleton, particularly those related to osteoporosis (distal third of the radius and proximal region of the femur).

This study shows that most insufficiency fractures of the spine are not isolated, because all the 14 subjects with fractures had fractures in more than one vertebra. Due to the low number of research subjects, it was not possible to correlate the level of the fractures with the distribution of the curves of the sagittal plane of the spine.

\section{CONCLUSION}

Elderly patients who have suffered insufficiency fractures in the proximal region of the femur should undergo spinal evaluation because there is a strong association between them and fractures of the vertebral bodies. A semiquantitative evaluation of the vertebrae to calculate the SDI should be conducted and used for future evaluations for the diagnosis of incidental fractures. Although these fractures seem small when evaluated separately, the sum total of vertebral changes constitutes a risk for the patient. Efforts should be focused on early diagnosis and intervention, before fractures with higher morbidity and mortality occur.

All authors declare no potential conflict of interest concerning this article.

\section{REFERENCES}

1. Kerkeni S, Kolta S, Fechtenbaum J, Roux C. Spinal deformity index (SDI) is a good predictor of incident vertebral fractures. Osteoporos Int. 2009;20(9):1547-52.

2. Lindsay R, Silverman SL, Cooper C, Hanley DA, Barton I, Broy SB, et al. Risk of new vertebral fracture in the year following a fracture. JAMA. 2001;285(3):320-3.

3. Ettinger B, Black DM, Nevitt MC, Rundle AC, Cauley JA, Cummings SR, et al. Contribution of vertebral deformities to chronic back pain and disability. The Study of Osteoporotic Fractures Research Group. J Bone Miner Res. 1992;7(4):449-56.

4. Binkley N, Krueger D, Gangnon R, Genant HK, Drezner MK. Lateral vertebral assessment: a valuable technique to detect clinically significant vertebral fractures. Osteoporos Int. 2005:16(12):1513-8.

5. Nevitt MC, Ettinger B, Black DM, Stone K, Jamal SA, Ensrud K, et al. The association of radiographically detected vertebral fractures with back pain and function: a prospective study. Ann Intern Med. 1998:128(10):793-800.

6. Roux C, Fechtenbaum J, Kolta S, Briot K, Girard M. Mild prevalent and incident vertebral fractures are risk factors for new fractures. Osteoporos Int. 2007;18(12):1617-24.

7. Crans GG, Genant HK, Krege JH. Prognostic utility of a semiquantitative spinal deformity index. Bone. 2005;37(2):175-9.

8. Faisal-Cury A, Zacchello KP. Osteoporose: prevalência e fatores de risco em mulheres de clínica privada maiores de 49 anos de idade. Acta Ortop Bras. 2007;15(3):146-50.

9. Costa-Paiva L, Horovitz AP, Santos AO, Fonsechi-Carvasan GA, Pinto-Neto AM. Prevalência de Osteoporose em Mulheres na Pós-menopausa e Associação com Fatores Clínicos e Reprodutivos. Rev Bras Ginecol Obstetr. 2003;25(7):507-12.
10. Genant HK, Jergas M, Palermo L, Nevitt M, Valentin RS, et al. Comparison of semiquantitative visual and quantitative morphometric assessment of prevalent and incident vertebral fractures in osteoporosis The Study of Osteoporotic Fractures Research Group. J Bone Miner Res. 1996;11(7):984-96.

11. Genant HK, Wu CY, van Kuijk C, Nevitt MC. Vertebral fracture assessment using a semiquantitative technique. J Bone Miner Res. 1993:8(9):1137-48.

12. Grados F, Roux C, de Vernejoul MC, Utard G, Sebert JL, Fardellone P. Comparison of four morphometric definitions and a semiquantitative consensus reading for assessing prevalent vertebral fractures. Osteoporos Int. 2001;12(9):716-22.

13. Schwartz EN, Steinberg D. Detection of vertebral fractures. Curr Osteoporos Rep. 2005;3(4):126-35.

14. Schousboe JT, Vokes T, Broy SB, Ferrar L, McKiernan F, Roux C, et al. Vertebral fracture assessment: the 2007 ISCD Official Positions. J Clin Densitom. 2008:11(1):92-108.

15. Black DM, Palermo L, Nevitt MC, Genant HK, Epstein R, San Valentin R, et al. Comparison of methods for defining prevalent vertebral deformities: the study of osteoporotic fractures. J Bone Miner Res. 1995;10(6):890-902.

16. Genant HK, Jergas M. Assessment of prevalent and incident vertebral fracture in osteoporosis research. Osteoporos Int. 2003;14(Suppl 3):43-55

17. Guglielmi G, Diacinti D, van Kuijk C, Aparisi F, Krestan C, Adams JE, et al. Vertebral morphometry: current methods and recent advances. Eur Radiol. 2008;18(7):1484-96.

18. Russel TA. Intertrochanteric fractures. In: Bucholz RW, Heckman JD, Court-Brown CM, Tor netta P 3rd, editors. Rockwood and Green's fractures in adults. 7th ed. 2009. p. 1597-640. 